\title{
Circo e teatro: aproximações e conflitos
}

\section{Um pouco de história}

J esde que se constituiu como espetáculo, no formato moderno do termo, no final do século XVIII, o circo vem despertando o interesse de uma gama ampla de artistas, em praticamente todas as linguagens. No campo das artes plásticas, por exemplo, o circo encantou e inspirou artistas das mais díspares tendências. ${ }^{1}$ Chaplin, Irmãos Marx, Fellini, Bergman e vários outros cineastas se dedicaram ao assunto. Dado o seu potencial cênico antiilusionista, os teatrólogos do início do século $\mathrm{XX}$ que investiram no rompimento com a cena realista não escaparam ao encanto do circo. Encenadores, cenógrafos, iluminadores e atores foram buscar, desde o início, no circo, motivos para a criação teatral. Antes disso, os românticos encantaram-se com o circo e freqüentaram assiduamente seus espetáculos. Os simbolistas,

\author{
Mario Fernando Bolognesi
}

um pouco depois deles, também viram no circo e no palhaço signos quase que privilegiados para suas aspiraçôes em torno da poética do etéreo e do inefável. ${ }^{2}$ Com o teatro dos gêneros ditos "menores", o intercâmbio com o circo foi dos mais intensos. O Teatro das Feiras parisiense sempre manteve um contato estreito com as artes circenses, antes mesmo do circo moderno se constituir. Os movimentos de vanguarda, especialmente na Rússia, a partir do cubo-futurismo, deixaram obras que se inspiraram no universo circense, especialmente porque estavam interessados em se distanciar do teatro naturalista, e psicológico, predominante nos palcos russos no início do século XX. ${ }^{3}$

$\mathrm{Na}$ outra via dessa mesma mão, o circo também encontrou no teatro muitas possibilidades de ampliação de seu espetáculo. Esquetes, mimodramas e hipodramas, desde a formação do circo, compunham o conjunto apresentado

Mario Fernando Bolognesi é professor do Instituto de Artes da Unesp e pesquisador do CNPq.

1 O ensaio de Starobinski é um ótimo apanhado crítico dessa apropriação.

2 Ver, por exemplo, O barracão de feiras, de Blok, e Aquele que leva bordoadas, de Andreiev, encenada em 2005, no Teatro Popular do Sesi, de São Paulo, sob direção de Antonio Abujamra.

3 Maiakóvski (aliado ao trabalho do encenador Meyerhold) escreveu várias peças a partir da estrutura espetacular circense: Campeonato universal da luta de classe; Moscou em chamas, Mistério bufo etc. Ver Bolognesi, 2004. 
no picadeiro. ${ }^{4} \mathrm{O}$ espetáculo consolidado por Philip Astley em seu Anfiteatro londrino, em 1769, era composto, primordialmente, de números eqüestres, na modalidade volteio. ${ }^{5}$ Após a migração temporária de Astley para Paris, onde encontrou Antonio Franconi, um outro empreendedor de espetáculos de variedades, o espetáculo com cavalos foi aos poucos recebendo a incorporação dos saltimbancos, dos artistas dos teatros das feiras, dos ciganos, dos remanescentes da commedia dell'arte, de amestradores de animais ferozes e selvagens etc. Isto é, o espetáculo de variedades e atrações manteve, desde seus primeiros tempos, um estreito relacionamento com o fazer teatral, especialmente aquele praticado nos tablados, nos teatros das feiras e dos bulevares.

Após 1789, especialmente na França, com a Restauração, as investidas napoleônicas e a consolidação da imagem do Imperador induziram o espetáculo circense a tratar de "temas históricos". Cavalos, feras amestradas das mais diversas partes do mundo, dominadas pelo homem, números os mais variados, encenados com figurinos alusivos a lugares conhecidos (quase sempre, conquistados), eram material mais que adequado e suficiente para a criação dos hipodramas históricos, espetáculos feéricos e grandiosos que narravam as proezas do conquistador. O que estava em jogo era a consolidação de uma classe social que ascendeu ao poder e a correlata idéia de Nação por ela defendida. O circo e seu espetáculo, que em seus primórdios estava direcionado ao público burguês, foi a ferramenta espetacular de tamanha façanha.
Para esse intento, os diretores de circo buscaram inspiração nas mais diversas fontes. Duas delas merecem registro: uma primeira, de matriz literária, com a criação do hipodrama $\mathrm{Maz}$ zeppa, inspirado em poesia de Lord Byron; outra, de natureza histórica, $A$ batalha de Waterloo, ou mesmo A tomada da Bastilha. ${ }^{6}$

Paralelamente a esse tipo de espetáculo de acentuado teor político, em perfeita sintonia com o ideário romântico francês, um outro espetáculo era oferecido nas periferias de Paris. Neste, gigantes, anões, siamesas, amestradores de cães, gatos, ursos e cobras, pirofagistas, duelos de touros com leões e cachorros, mulheres e homens com forças descomunais e toda uma série de excentricidades ("anomalias”, "aberraçôes", "exposição e exploração das deformidades da civilização", diriam alguns) se apresentavam em pequenos espaços, para um público não burguês. Esses espetáculos também comportavam seu lado "teatral", pois esquetes adaptados dos roteiros da commedia dell'arte e dos teatros das feiras eram igualmente apresentados, sob a presença imperativa do clown mímico (é preciso lembrar que o uso da palavra em espetáculos era proibido em Paris, exceto na Comèdie Française, no Opéra e na Comèdie Italienne, regra esta que só foi abolida definitivamente em 1864).

\section{E o Brasil?}

No Brasil, a aproximação do circo com o teatro, que sempre é permeada de conflitos, ${ }^{7}$ também ocorreu e os modernistas (particularmente

4 No capítulo "O corpo como princípio", de meu livro Palhaços, eu discorro pormenorizadamente sobre os contatos dos circenses com o teatro, em suas várias modalidades.

5 Astley teve antecessores. Em Viena, desde 1755, Français Defraine oferecia espetáculos de caça ao javali e ao cervo, combate de animais e exibição eqüestre, em pista circular, em um anfiteatro ao ar livre. O próprio Astley, antes de construir seu Anfiteatro em madeira, apresentava exercícios eqüestres ao ar livre (Hotier, 1995, p. 52).

6 Saxon (1968) dedicou-se à história do hipodrama.

7 Ver o artigo de Ermínia Silva, nesta edição. 
Oswald de Andrade) não são (ou foram) exceção. Além de cenas curtas e de esquetes cômicos, por aqui, como também na Argentina, consolidou-se uma modalidade que fez (e ainda faz) história: o circo-teatro, que deve ao palhaço negro, Benjamin de Oliveira, a sua consolidação. ${ }^{8}$ Em tempos mais recentes, esse contato tem sido intenso. A aproximação da cena teatral com o picadeiro envolve o domínio das várias facetas acrobáticas, que ganham novos sentidos a partir das lentes do teatro e da dança. Esse movimento de re-aproximação pode ser detectado a partir do final dos anos de 1970. A criação das várias escolas de circo, no País, facilitou a aproximação dos artistas do teatro com o circo. A Academia Piolim de Artes Circenses, em São Paulo, foi a primeira iniciativa de transferir o conhecimento artístico circense para fora dos limites da lona. Na década seguinte, em 1982, o Governo Federal criou a Escola Nacional de Circo. Iniciativas privadas se seguiram e, em 1984, foi criado o Circo Escola Picadeiro, em São Paulo, e um ano depois a Escola Picolino de Circo, em Salvador. A partir de então, escolas de circo proliferaram por todo o território nacional e hoje são locais importantes para o aprendizado circense. ${ }^{9}$

Contudo, na história recente, antes mesmo da criação das escolas de circo, artistas e grupos - pelo menos em São Paulo - já se interessavam pelo linguajar circense, a exemplo do
Grupo de Teatro Mambembe, que investigou a comicidade do palhaço circense. ${ }^{10}$ As experiências do Ornitorrinco, dirigidas por Cacá Rosset, especialmente as montagens de Molière, além do $U b u$, também procuraram a aproximação da cena com a linguagem circense. ${ }^{11}$ Essas experiências apontam para duas modalidades distintas de apropriação, por parte do teatro, da linguagem circense. Uma terceira experiência deve ainda ser registrada. Trata-se do grupo Tenda Tela Teatro, vinculado à Cooperativa Paulista de Teatro. A partir de 1982, esse grupo procurou o aprendizado circense nos circos da periferia de São Paulo, em um momento em que a Academia Piolim já não mais existia e a escola Picadeiro ainda não havia sido inaugurada. Inicialmente, o objetivo era a integração das linguagens do circo, do teatro e da dança. No entanto, o grupo tomou um outro rumo: comprou uma lona e criou o Metrópole Arte Circo. Em seus espetáculos apareciam os elementos teatrais e coreográficos, com fábulas e enredos nos números circenses (Mostaço, 1986).

Esses são três apenas exemplos, dentre muitos outros. ${ }^{12}$ Eles são significativos, pois apontam para três tendências distintas: o Mambembe foi, prioritariamente, em busca das características da interpretação cômica do palhaço e freqüentou assiduamente os espetáculos do palhaço Chico Biruta (Marco Antônio Martini), do Circo Teatro Bandeirantes, na periferia

8 Ver, a respeito, Duarte (1995), Silva (1996 e 2004) e Marques (2005). O circo-teatro está presente nos Estados do sul do País, que concentram companhias que se dedicam exclusivamente a essa modalidade cênica circense. Neste dossiê, vários artigos fazem referência ao circo-teatro: Para o caso argentino, consultar o artigo de André Carreira; Daniel Marques faz uma apresentação de Benjamin de Oliveira; o artigo de Paulo Merisio apresenta algumas das características do melodrama; Ermínia Silva aborda a teatralidade circense a partir de Arthur Azevedo.

9 Consultar o site da Associação Brasileira de Escolas de Circo <www.abecirco.com.br> ou ainda o site $<$ www.pindoramacircus.com.br $>$.

Ver o estudo de Rubens José Souza Brito, nesta edição.

11 Ver o estudo de Berenice Albuquerque Raulino de Oliveira, nesta edição.

12 Outros grupos se sobressaíram nos anos de 1980, a exemplo do Abracadabra, que merece investigação mais detalhada. 
da cidade de São Paulo; o Ornitorrinco interessou-se pelo caráter feérico e espetacular das artes circenses e se apropriou dos ensinamentos de José Wilson Moura Leite, criador e diretor do Circo Escola Picadeiro; o Tenda Tela Teatro também iniciou o aprendizado com José Wilson, no Circo Royal, além de freqüentar várias outras companhias que se apresentavam na periferia paulistana (Circo Wallace, Circo Real Madri, entre outros). Talvez, por isso, o grupo voltou-se para o espetáculo circense.

Nas décadas seguintes, na cidade de São Paulo, essas três tendências foram aprofundadas. A comicidade teatral apreendida no âmbito circense é desenvolvida por vários grupos, tais como a Fraternal Companhia de Arte e MalasArtes, Parlapatôes, Patifes e Paspalhões, Raso da Catarina, Clā, Jogando no Quintal, Circo Navegador, La Mínima etc. A adoção dos números circenses e a exploração de seu potencial dramático podem ser detectadas nos trabalhos do Circo Mínimo, Linhas Aéreas, Fractons, Nau de Ícaros, dentre outros. Alguns grupos também se direcionaram para o espetáculo circense instalado sob lona, como o Circo Zanni e o Circo Roda Brasil, o mais recente. ${ }^{13}$ As técnicas representativas dos palhaços têm hoje presença marcante no ensino e no aprendizado dos atores, especialmente porque estão associadas ao trabalho com as máscaras. ${ }^{14}$

\section{Entre o "novo" e o "tradicional"}

Os espetáculos circenses, acompanhando a tendência das aproximações, a partir dos anos de 1980, também sofreram transformações significativas. Houve mudanças coreográficas, cenográficas, de figurino, de repertório musical e de concepção do espetáculo.

Algo que chama a atenção nessa transformação é a abolição da presença do apresentador no espetáculo. Os espetáculos desta nova tendência, denominada (erroneamente, na minha concepção, conforme se demonstrará) de "circo novo" ou "circo contemporâneo", abdicam do fator "épico" e comunicativo do espetáculo para investir no aspecto, pode-se dizer, "dramático" e expressivo. ${ }^{15} \mathrm{O}$ espetáculo e os números, com isso, fecham-se em si mesmos e a platéia é colocada na condição de espectadora quase que passiva: o público é concebido como receptor de um espetáculo que se desenrola por si e em si. O espetáculo circense, que sempre primou por criar relações e contatos com o público, ${ }^{16}$ tende agora a dissipar essa característica. Esta concepção quer colocar o público circense na mesma condição de fruição artística distanciada, marcas originais dos conceitos de arte e da estética que a acompanha, tal como consolidada pelo pensamento filosófico, a partir do século XVIII. O objetivo é alçar o espetáculo à condição de "belo". ${ }^{17}$

13 O histórico e os propósitos desses grupos citados podem ser consultados no Anuário de teatro de grupo da cidade de São Paulo 2004.

14 O artigo de Felisberto Sabino da Costa, integrante deste dossiê, aborda o lugar da máscara na formação do ator brasileiro, na atualidade.

15 Os termos "épico" e "dramático" são utilizados nos sentidos dados pela moderna teoria do teatro, particularmente cunhados por Bertolt Brecht, e não nos sentidos clássicos da teoria dos gêneros.

16 “O espetáculo não é uma arte, ele é uma relação" (Hotier, 1995, p. 48).

17 No último capítulo de meu livro Palhaços eu discorro sobre este assunto, enfatizando que o espetáculo circense se fundamenta não exatamente no belo, mas sim no trânsito entre o sublime e o grotesco. 
Do ponto de vista histórico, não há razão alguma para se denominar este movimento como "novo" ou "contemporâneo". Os termos são imprecisos, justamente porque, desde seus passos juvenis, o circo sempre dialogou e incorporou as inovações dramáticas e teatrais. Como já ficou salientado, os hipodramas, ou pantomimas eqüestres, na França, por exemplo, eram grandes encenações com dramaturgia, direção, interpretação e etc., dos feitos militares, especialmente de Napoleão e de suas conquistas. Obras de Shakespeare e de muitos outros autores teatrais foram adaptadas para serem levadas ao picadeiro, com os recursos comunicativos da linguagem circense. $\mathrm{O}$ diferencial é que as cenas circenses nunca almejaram o fechar-se entre quatro paredes, tal como sugere a atual tendência dominante.

Diferentemente dos liames teatrais que o circo consolidou na Europa, quando Phineas Taylor Barnum, em 1850, levou o espetáculo para os Estados Unidos, ele se afastou da linhagem cênica explorada por Astley e Franconi e optou pelo side-show. Neste modelo, além dos números eqüestres, Barnum retomou a fórmula das festas européias, àquela altura em franca decadência, e valorizou as apresentações artísticas dos saltimbancos e artistas das feiras. Suas atrações envolviam animais adestrados, exposição de fenômenos humanos como mulheres barbadas, anões, gigantes, obesos, além de antipodistas, funâmbulos, acrobatas, etc. No entanto, diferentemente da exposição direta, tal como ocorria nas feiras, Barnum investiu na destreza corporal das anormalidades, desenvolvendo uma "ginástica das disposiçóes anormais, produzindo um trabalho que se pode considerar como uma variante espetacular da acrobacia: os desarticulados e os deslocados" (Auguet, 1974, p. 116). Além disso, o circo, nos Estados Uni- dos da América, teve de resolver uma outra ordem de problema: como percorrer as grandes distâncias e como se apresentar em localidades desprovidas de um local apropriado? Edifícios para espetáculos não eram comuns em solo norte-americano. O uso da estrada de ferro e a abertura para as várias modalidades de circo de lona foram as principais soluções. A errância estava de volta, em um espetáculo de atrações apresentado em um espaço próprio. Esse modelo progrediu sobremaneira, até chegar às grandes companhias, com três picadeiros simultâneos.

O espetáculo circense - no século XX em especial - investiu e encontrou uma especificidade cênica: ele se depurou enquanto linguagem, aprofundando o fator acrobático e feérico, a ponto de conseguir se desvencilhar, quase que totalmente, da dependência da cena teatral. Ele buscou um grau zero de representação, livrando-se do verossímil como critério de constituição cênica. Não há possibilidade alguma de um acrobata "representar" um salto, ou de um trapezista "interpretar" o tão sublimado triplo salto mortal no trapézio voador. ${ }^{18} \mathrm{O}$ circo e sua linguagem encontraram uma especificidade que os diferenciaram das demais modalidades cênicas, sem se chocar com os esportes. A exceção ainda ficou por conta dos números de magia, quando, a partir da atuação do artista, a ilusão é condição necessária para o bom desempenho. Ou seja: no que diz respeito ao número de magia, o público, de certa forma, sabe antecipadamente tratar-se de um truque, de um engano, mas a eficácia do número é plenamente alcançada quando o público se regozija neste engano e nesta ilusão. A platéia quer ser "bem enganada" e isso é obra exclusiva do potencial do ator que se coloca na condição de mágico ou prestidigitador. Outro elemento fundado na representação, que o circo manteve, é o jogo

18 Apenas para efeito de informação, desde há muito o triplo salto mortal, no trapézio voador, foi superado. Na década de 1980, no Brasil, os Irmãos Alves já executavam o quádruplo e preparavam o quádruplo e meio. 
cênico dos palhaços. Mas, aqui também, a verossimilhança foi efetivamente abandonada em nome de uma interpretação farsesca em que o exagero e o absurdo grotescos são elevados à potência máxima.

$\mathrm{Na}$ história do circo, o século XX trouxe o ganho dessa especificidade, que hoje é denominada de "tradicional", em oposição ao "novo", que nada mais é do que a retomada do potencial cênico e coreográfico que nos séculos anteriores, na Europa, o espetáculo circense tinha cultuado. Por essas razôes, as qualificações estão invertidas. O "novo", 19 tal como denominado hoje em dia, é o "tradicional" da história do espetáculo circense e o chamado "tradicional” foi a novidade que o circo alcançou no século passado. Talvez possamos argumentar que esta especificidade artística se esgotou, que ela se tornou repetitiva etc. Mas, mesmo o esgotamento - se ele houver - e a repetição - se ela de fato persistir - não são critérios sólidos para a proposição dos termos, ou para estabelecer as diferenciações propostas.

\section{O palhaço e a cena}

Tal como o circo em seu todo, os palhaços circenses também foram apropriados pelos artistas do teatro. Em São Paulo, podem ser identificadas três matrizes da adoção das personagens cômicas circenses para a cena: a do circo propriamente dito, através das escolas, ou diretamente com os circos itinerantes; as investigaçōes do Lume, de Campinas, que têm o clown como passagem da pré-expressividade à expressividade (Feracini, 2001, p.217-232); e as iniciativas de Maria Helena Lopes, da UFRGS, e Elizabeth Lopes, da Unicamp, além do italiano Francesco Zigrino, na década de 1980. ${ }^{20}$ Através dessas últimas referências nacionais, atores e diretores teatrais tiveram a oportunidade de experimentar técnicas as clownescas filtradas por diretores franceses, especialmente Decroux e Lecoq.

Afora as poucas exceções de sempre, na apropriação do palhaço tem predominado uma vertente que procura um viés psicológico extremado e tanto busca descobrir o "ridículo" em cada ator como promove uma cristalização da personagem e da cena, garantida por uma dramaturgia específica e, entre outras características, "domesticadora" da personagem. As atribuições grotescas e populares do palhaço de circo, que são, concomitantemente, universal e particular (Bolognesi, 2003, p. 57-90), foram (e estão sendo) preteridas e substituídas pela nuança naturalista da máscara clownesca, com base no princípio da verossimilhança.

Essa distância se reflete, inclusive, na proposta de diferenciação terminológica entre palhaço e clown. ${ }^{21}$ Embora oriundas de campos lingüísticos diversos (italiano, para o "palhaço"; anglo-saxão, para o "clown"), do ponto de vista semântico os dois termos são similares: tolo, rústico, camponês, de raciocínio lento etc. No ambiente do circo, os clowns ganharam uma polaridade que foi vital para a consolidação da dupla cênica: Clown Branco e Augusto se firmaram como oposiçõos necessárias ao conflito cômico circense. O primeiro é a ordem e a au-

19 Em 26 de Novembro de 1881, foi inaugurada em Paris uma Arena Náutica. A piscina ocupava toda a área de um picadeiro e o espetáculo se desenrolava nessa arena. Imediatamente, tal empreitada foi batizada de Novo Circo. Isto é, nem o termo é original.

20 Ver, a respeito, Costa, 2006, p. 32-35 e 45-54; Santos, 2006, além do artigo de Felisberto Sabino da Costa que integra esta seção de Sala Preta.

21 No universo circense brasileiro, essa diferenciação soa estranha, já que ambos os termos designam funçôes distintas do cômico do picadeiro: o clown é o escada; o palhaço é uma designação geral para o augusto, o toni de soirée, o excêntrico, etc. 
toridade; o segundo, a desordem, a ruptura e a sublevação. O Branco é a sutileza e a conclamação do sublime; o Augusto, o rude e a evidência da fome. O Branco é o espírito da civilização; o Augusto, o corpo agrilhoado desta mesma civilização, que quer se rebelar.

A individualização e "psicologização" do clown provocam uma inversão nessa ordem de contrários: adotam-se a vestimenta exagerada, a maquiagem forte e o nariz vermelho do Augusto, mas subtrai-se dele a manifestação revoltosa do corpo subjugado e, em seu lugar, dota-se a personagem de laivos poéticos e espirituais. Termina prevalecendo, no Augusto, a sublimidade do Clown Branco. O conflito (que remete às ordens do social e do psicológico) foi suprimido em nome de uma expressividade cênica que exalta o ridículo aceitável. ${ }^{22}$ Em outras palavras, esse processo internaliza, no dominado, a voz do dominador. $\mathrm{O}$ corpo está definitivamente controlado pelo privilégio da ilusão dos atos do pensamento e da poesia, próprios do espírito.

Mas, pensando nas profundas diferenças entre os modos de interpretação e encenação do palhaço no ambiente épico do circo e no dramático do teatro, talvez a diferenciação seja proveitosa, pois demarca, possivelmente, uma nova etapa na história do clowns, desta feita voltada especificamente para o palco teatral, seja ele em espaços fechados, em ruas ou praças. Se uma diferenciação se fizer necessária, seria conveniente, no entanto, encontrar um outro termo para não sufocar a figura cênica originária do clown, incorporada e lapidada pela comicidade circense.

O clown, tal como apropriado e desenvolvido na maioria dos grupos e artistas de teatro, se transformou em figura emblemática e poética, portador de uma poesia própria, essencialmente etérea. Isto é, esta tendência enfatiza o gracioso, em detrimento do grotesco; investe na ironia, enfraquecendo a sátira e a paródia.
Em poucas palavras, este protótipo de clown passou por um profundo processo de subjetivação e individualização, a ponto de abandonar as características cômicas grotescas que o consagraram. As marcas do corpo (o corpo é a "alma do palhaço"), subjugado à autoridade e à ordem, privado do alimento, do amor e do sexo, estão ainda mais escamoteadas. Do ponto de vista da história das artes cênicas, algo similar se deu com os românticos e os simbolistas, quando se voltaram para o universo circense e para os palhaços. Ou para dizer o mesmo de outra maneira, a tendência atual parece se configurar como um reviver da atitude simbolista, fortemente marcada por uma tonalidade poética.

Conseqüências desta tendência podem ser vistas no abandono do caráter improvisado da interpretação do palhaço, bem como no enquadramento da encenação em uma dramaturgia fixa. O apoio a uma dramaturgia sucinta, um simples roteiro de cena, e a liberdade da interpretação improvisada (que tem o público como elemento essencial, uma espécie de terceira personagem), características da atuação do palhaço circense, foram abandonados em nome da dramaturgia fechada e da encenação minuciosa. Ambas prevêem e indicam os rumos da interpretação. Com isso, abandona-se o aspecto épico-comunicativo do circo e adota-se uma postura dramática, expositora de uma individualidade exclusiva. O público, de participante, passa a receptor. A iluminação, geral e aberta, que mostra o público, adotou o foco que centraliza a personagem e seus dilemas.

No Encontro Mundial de Palhaços, ocorrido em João Pessoa (PB), em 2001, participaram vários artistas e trupes nacionais e estrangeiras. A maioria era de artistas que se apropriam da personagem palhaço para os espetáculos de palco, obedecendo à tendência de buscar na linguagem circense as formas de renovação do espetáculo teatral. Foram poucas as

22 Não seria exagero apontar uma tendência de satisfazer os ditames do "politicamente correto". 
apresentações de palhaços que desenvolvem seu trabalho nos picadeiros de circo. O Encontro, portanto, centrou-se nos jovens talentos teatrais que desenvolvem cenas e personagens cômicas, explorando sobremaneira a mímica, porém descuidando de um importante aspecto da arte do palhaço circense, qual seja, a interação improvisada e contínua com o público. Ao contrário da luz geral aberta, que é própria do circo, aqui a opção recai sobre o foco direcionado, mantendo o público na escuridão, tal como no teatro.

No circo, o público participa ativamente do desempenho do palhaço, inclusive direcionando, no ato do improvisar, a expansão ou o retraimento das entradas e reprises (seria demais chamar a isso de "dramaturgia aberta"?). Essa característica tem sido abandonada pelos artistas do palco que adotam o palhaço como forma expressiva. ${ }^{23} \mathrm{~A}$ preferência tem recaído sobre uma dramaturgia que fixa concretamente as várias ações cênicas. ${ }^{24}$

Processo similar de enquadramento dramatúrgico ocorreu com as máscaras da Commedia dell'arte (uma invenção romântica segundo Cuppone, 1999, p. 23-32), quando de sua instalação na França, a partir do final século XVII e especialmente no XVIII. O Teatro das Feiras de Paris, principalmente através de Lesage (autor que ficou conhecido como o Molière das Feiras), não mediu esforços para moldar as máscaras dell'arte aos cânones da verossimilhança, fazendo com que a ilusão se firmasse como critério de renovação. Esse processo de "naturalização" das máscaras transformou os tipos originais. Para tal efeito, a dramaturgia teve papel significativo: ela procurou estabelecer previamente aquilo que em sua manifestação original se fundamentava na improvisação e na habilidade do ator. O resultado, na Commedia dell'arte, dentre outros, foi a formalização e a estilização. A título de exemplo, o primeiro Arlecchino, astuto, agressivo, em farrapos, sofreu alteraçôes significativas e se transformou em uma personagem formal: os farrapos de sua vestimenta tornaram-se losangos. Isto é, a personagem foi amalgamada às características do país que o acolheu: sua comicidade tornou-se prioritariamente verbal, com apoio em uma dramaturgia prévia, em detrimento da mímico-gestual na qual se originou. A interpretação corporal e acrobática foi se arrefecendo e cedeu o posto à interpretação a partir do pensamento e da palavra. Ou seja, na França, as máscaras dell'arte se submeteram a um processo de aburguesamento, tornando-se palatáveis à nova classe social que ganhava força e que freqüentava os teatros. Arlequim tornou-se gentil, galante, cerimonioso e sentimental (Vinti, 1989, p. 39).

Acompanharam o processo de espiritualização, com ênfase na sentimentalidade característica à subjetivação da personagem-tipo, a substituição dos lazzi pela ênfase verbal, a gestualidade puramente corporal em jogo lingüístico de destrutiva ironia (destrutiva, porque a ironia parte do principio da superioridade daquele que ironiza sobre quem é ironizado), a substituição de uma dramaturgia aberta e dependente da improvisação por um texto e espetáculo que se fecham em si.

Tal como as máscaras dell'Arte, o palhaço, através da encenação e da dramaturgia contemporâneas, está passando por processo similar de enquadramento "civilizatório", isto é, modelando-se às características dominantes da

23 Evidentemente, há exceções. No Encontro de João Pessoa, de tudo o que pude assistir, dentre os palhaços brasileiros, apenas os Parlapatôes e, parcialmente, o palhaço Xuxu (Luiz Carlos Vasconcelos) procuraram um diálogo com a platéia.

24 Mas, por outro lado, muitos artistas do palco se apropriam do repertório cômico circense e promovem criações de novas entradas e reprises, contribuindo para a expansão da dramaturgia cômica. 
cena atual, arrefecendo os impulsos corporais da fome e do sexo e enaltecendo o jogo do espírito. O palhaço, com isso, deixa de ser o estranho, o intruso, o sem-lugar, para ocupar um posto na espetacularidade social, como se o processo da dominação, escamoteando suas próprias características de exclusão, incluísse os deserdados. Os graves problemas, que não se resolvem no âmbito social, serão absorvidos e anulados no espetáculo.

\section{Uma reflexão final}

Seguindo as trilhas de Vinti, que detectou o aburguesamento do Arlequim, a tendência de enquadrar o feérico-épico circense e seu necessário contraponto grotesco dos palhaços nos ditames da cena de cunho dramático não estaria respondendo às necessidades dominantes de nossa época? $\mathrm{Na}$ conclusão de meu livro sobre os palhaços brasileiros já intuí que sim, apontando para a supressão do antagonismo. Afirmei na oportunidade: "De fato, essa tendência pode ser a mais apropriada para esses tempos que querem abolir a idéia de luta, de opostos, de opressão. Com isso, tem-se um esvaziamento da dimensão política do palhaço em nome de um ideal poético metafísico" (2003, p. 200-1). No horizonte desta tendência e desta forma de apropriação do circo e dos palhaços, não há motivos para voltar atrás na conclusão. Não seria este um movimento que tende a tornar palatável às inteligências das platéias freqüentadoras das casas de espetáculos aquilo que o circo apresenta e oferece como sensorial? As excentricidades humanas, transformadas no circo em matéria espetacular, são simplesmente abolidas por conta de uma consciência política que não admite a existência artística do diferente. Mas, não seria esta uma forma de segregação, na medida em que procura esconder aquilo que the contraria? Anões, gigantes, obesos e demais excentricidades não podem ser alçados à condição de artistas unicamente a partir de suas características corporais? Teriam eles de se transforma- rem em escritores, dramaturgos, diretores, cineastas e demais categorias vinculadas às belas artes para serem reconhecidos artisticamente? $\mathrm{O}$ corpo e sua exposição oferecem riscos à supremacia do espírito.

A cultura e o pensamento, pilares da afirmação da superioridade de uns sobre os outros que, desde a Antigüidade, sob roupagens diversificadas, querem impor (e em muitos momentos conseguem com espantosa eficácia) a incompatibilidade entre o campo do espírito (no qual se incluem a arte e a cultura) e o mundo objetivo da matéria, o aqui e agora, parece que conseguiu adentrar no campo artístico da exclusividade corporal, esvaziando-o e o tornando beleza espiritual. Fruição estética e prazer artístico se apresentam dissociados das mazelas do cotidiano. Ou:

“...num mundo de infelicidade, a felicidade sempre precisa ser um consolo: o consolo do instante belo na seqüência interminável da infelicidade. $\mathrm{O}$ prazer da felicidade é confinado no instante de um episódio. Mas o instante contém em si a amargura de seu desaparecimento. E no isolamento dos indivíduos solitários não existe ninguém com quem a felicidade própria estaria preservada após o desaparecimento do instante, ninguém que não fosse vítima da mesma solidão. O efêmero que não deixa atrás de si uma solidariedade dos sobreviventes necessita ser eternizado para poder ser suportado, pois se repete em cada instante da existência e antecipa a morte também em cada instante. Uma vez que cada instante porta em si a morte, o instante belo precisa ser perpetuado como tal, para tornar possível algo como a felicidade. A cultura afirmativa eterniza $\mathrm{o}$ instante belo na felicidade que ela proporciona; ela eterniza o efêmero" (Marcuse, 1997, p. 117).

O circo e seus palhaços, em sua versão chamada "tradicional", absorvidos certamente (mais do que todas as outras artes) pela conversão da arte em mercadoria, estariam fadados 
à condição de puro divertimento e, nesse sentido, peças participantes do papel afirmativo da cultura e das artes. Isso teria plena vigência se ele concebesse seu desempenho espetacular tendo como ponto de chegada os indivíduos isolados. Mas não: nele, não são personagens individualizados que expóem seus dilemas e angústias. Ele enfatiza a potencialidade corporal de homens e mulheres, que oscila, de um lado, entre o arrepio, o espanto e o medo diante da evolução acrobática arriscada e sublime e, de outro, tende imediatamente para a exposição do corpo dominado, que expõe sua condição submissa através da hipérbole do grotesco. Esse jogo de contrários, no nível da percepção da platéia, enfatiza a potencialidade do corpo frente à dominação intelectualista do espírito. Essa via, sensorial por excelência, se bem explorada, pode aguçar os conflitos que querem passar despercebidos. O caminho para tanto não parece ser o do psicológico, que expõe (quando expõe) a contradição unicamente no âmbito individual. 


\section{Referências bibliográficas}

AUGUET, R. Histoire et légende du cirque. Paris: Flammarion, 1974.

BOLOGNESI, M. F. Palhaços. São Paulo: Editora Unesp, 2003. . 1905 - As cidades de Maiakóvski. Urdimento Revista de Estudo Pós-Graduados em Artes Cênicas. Florianópolis: UDESC/CEART, 2004, v. 1, n. 6, p. 34-43.

COSTA, F. S. A outra face: a máscara e a (trans)formação do ator. São Paulo: ECA/USP, 2006. Tese de Livre-Docência.

CUPPONE, R. CDA. Il mito della commedia dell'arte nell'ottocento francese. Roma: Bulzoni, 1999.

FERRACINI, R. A arte de não interpretar como poesia corpórea do ator. Campinas: Ed.Unicamp, 2001.

HOTIER, H. Cirque, communication, culture. Bourdeaux: Presses Universitaires de Bourdeaux, 1995.

MARCUSE, H. O caráter afirmativo da cultura. Cultura e sociedade, v. 1. Rio de Janeiro: Paz e Terra, 1997.

MATE, A. (curador). Anuário de teatro de grupo da cidade de São Paulo 2004. São Paulo: Escritório das Artes, 2006.

MOSTAÇO, E. Gente que foge com o circo. Folha de São Paulo. São Paulo, 5 de março de 1986, p. 45.

SANTOS, L. R. A Linguagem das Máscaras por Francesco Zigrino. Anais do IV Congresso da ABRACE. Rio de Janeiro: ABRACE, 2006, p. 130-132.

SAXON, A. H. Enter foot and horse: a history of hippodrama in England and France. New Haven: Yale University Press, 1968.

STAROBINSKI, J. Portrait de l'artiste em saltinbanque. Genève: Albert Skira, 1970.

VINTI, C. Alla foire e dintorni. Roma: Edizioni di Storia e Letteratura, 1989. 